\title{
Genetic Variability, Correlation and Leaf Blast Resistance Studies in Early Maturing Rice Genotypes under Hilly Conditions
}

\author{
G.N. Hosagoudar ${ }^{1 *}$, Basavaraj S. Kovi ${ }^{2}$ and H.K. Sheela ${ }^{3}$ \\ ${ }^{1}$ Rice Pathologist and Head, AICRP on Rice, AHRS, Ponnampet, Karanataka, India \\ ${ }^{2}$ Rice Breeder on contract basis, AHRS, Ponnampet, Karanataka, India \\ ${ }^{3}$ Contract basis, AHRS, Ponnampet, Karanataka, India \\ *Corresponding author
}

\section{A B S T R A C T}

\section{Keywords \\ Hilly rice, Heritability, \\ Genetic advance, Correlation, Leaf blast. \\ Article Info \\ Accepted: \\ 26 October 2017 \\ Available Online: \\ 10 December 2017}

An experiment was carried out to screen for the blast disease and to estimate the genetic variability parameters and correlation patterns of yield and yield attributed characters in 18 rice genotypes under hilly conditions. Analysis of variance (ANOVA) revealed the existence of significant differences among genotypes for all traits studied. Genotypic coefficient of variation played a major role for the expression of the traits and ranged from 14.10 (Days to 50\% flowering) to 37.24 (grain yield/ha). Heritability ranged from 89.95 (grain yield/ha) to 98.91 (plant height). High genotypic variance and high heritability coupled with high genetic advance as percent of mean was found for number of panicles/plant $\left(21.20,92.17\right.$ and 41.92), number of panicles $/ \mathrm{m}^{2}(21.20,92.17$ and 41.92) and grain yield/ha $(37.24,89.95$ and 72.76$)$ respectively, indicated that high response to selection for these traits. On the basis of mean performance, out of eighteen entries 7 entries found resistant and remaining 11 entries found moderately resistant. Out of 7 resistant entries one entry namely IET-25148 recorded highest grain yield $(4562.27 \mathrm{Kg} / \mathrm{ha})$ and it was found $14.20 \%$ superior in grain yield than local check Tunga $(3101.42 \mathrm{Kg} / \mathrm{ha})$ followed by the moderately resistant entries IET-25144 (4250.89 Kg/ha) and IET-25151 $(4186.83 \mathrm{Kg} / \mathrm{ha}$ ) which found $11.09 \%$ and $10.44 \%$ superior in grain yield respectively. Traits which were positively correlated viz. days to $50 \%$ flowering $(0.47)$, number of panicles/plant $(0.92)$ and plant height $(0.26)$ could be used for their simultaneous improvement.

\section{Introduction}

Rice (Oryza sativa L.) is an important cereal crop belonging to family, Poaceae. It is cultivated over a wide range of climatic conditions; considered as a promising option for diversifying agriculture in various agroclimatic zones and ranks as second most important food crops in India. Rice together with Wheat and Maize provides at least 30\% of food calories to more than 4.5 billion people in 94 developing countries, where Rice is the preferred staple food. Being a major cereal food crop it contributes to food security in most of the developing countries. Rice provides $21 \%$ per capita energy and $15 \%$ per capita protein (Shrivastava et al., 2015). Globally, rice is cultivated in an area of about 161.40 million hectares and production of about 506.30 million tonnes with the productivity of 3.14 tonnes per hectare (Anon, 2015). Rice occupies a pivotal place in Indian 
agriculture and it contributes to around 17 percent of annual Gross Domestic Product (GDP) and provides 43 percent calorie requirement for more than 70 percent of the Indians. India ranks $1^{\text {st }}$ in area (43.49 million hectares) and $2^{\text {nd }}$ in production $(104.40$ million tonnes) after China (Anon, 2015). The average yield of rice in India is $2400 \mathrm{Kg} / \mathrm{ha}$. India exports 9.3 million tonnes of rice to the countries around the world (Anon, 2015). The major rice growing states in India are Karnataka, Andhra Pradesh, Bihar, Uttar Pradesh, Madhya Pradesh, West Bengal and Punjab. In Karnataka, rice is being cultivated in an area of 1.32 million hectare with the annual production of 3.54 million tonnes and productivity of 3.09 t/ha (Anon, 2014).

Although India has maximum acreage under cultivation among the rice growing countries, it lags behind with respect to productivity level. Low rice productivity is attributed to the lack of high yielding varieties, various biotic and abiotic stresses and several other constraints. Among various biotic stresses, leaf blast caused by Pyricularia grisea is one of the major diseases of rice causing substantial yield losses. Therefore, screening of advanced breeding lines for disease reaction helps in early identification and subsequent release of blast resistant varieties for commercial cultivation. In a rice improvement programme, it is the germplasm, which virtually determines the success and nature of end product. The development of superior rice population involves the perspicacious use of available genetic variability to cater the need of various farming situations of rice. The grain yield is the primary trait targeted for improvement of rice productivity in both favourable and unfavourable environments from its present level. Knowledge on the genetic architecture of genotypes is necessary to formulate efficient breeding methodology. It is essential to find out the relative magnitude of additive and non-additive genetic variances, heritability and genetic gain with regard to the characters of concern to the breeder. The systematic breeding programme involves the steps like creating genetic variability, practicing selection and utilization of selected genotypes to evolve promising varieties. The large spectrum genetic variability in segregating populations depends on the level of genetic diversity among genotypes offer better scope for selection. Heritability and genetic advance are other important selection parameters. The estimates of heritability help the plant breeder in determining the character for which selection would be rewarding. The breeders are interested in selection of superior genotypes based on their phenotypic expression. The major function of heritability estimates is to provide information on transmission of characters from the parents to the progeny. Heritability estimates can anticipate improvement by selection of useful characters. Heritability estimates along with genetic advance are normally more helpful in predicting the gain under selection than heritability estimates alone. Therefore, estimates of GCV, PCV, heritability and genetic advance will play an important role in exploiting future research projections of rice improvement. The present investigation was carried out to estimate the variability parameters among 18 rice genotypes.

\section{Materials and Methods}

The present experiment was carried out at Agricultural and Horticultural Research Station, Ponnampet, University of Agricultural and Horticultural Sciences, Shivamogga. Eighteen rice genotypes comprising of breeding lines from the AICRP trial and existing varieties were evaluated in randomized complete block design with two replications during Kharif 2015. Initially the seedlings were raised nursery and later 30 days seedlings were transplanted in a plot of 
$6.75 \mathrm{~m}^{2}$ size for each genotype by maintaining $15 \times 15 \mathrm{~cm}$ spacing. Agronomic practices were followed based on the zonal recommendations to raise a good and healthy crop. The observations were recorded on five randomly selected plants from each plot for quantitative traits namely plant height and panicle number per plant.

Panicle number $/ \mathrm{m}^{2}$ was taken on area basis, whereas days to $50 \%$ flowering and yield were taken on plot basis. Further the grain yield values recorded from the net plot (kg/plot) were converted into hectare $(\mathrm{kg} / \mathrm{ha})$. The AHRS, Ponnampet is considered as one of the hot spot for leaf blast disease hence genotypes were also evaluated for disease reaction under field condition and the genotypes were scored based on leaf blast severity following SES scale of IRRI (1996).

The mean data after computing for each character was subjected to standard method of analysis of variance following Panse and Sukhatme (1967), phenotypic and genotypic coefficient of variation were estimated by the formula as suggested by Burton(1952), heritability (broad sense) and genetic advance as per cent of mean were calculated by the formula given by Johanson et al., (1955). The simple correlation coefficients were calculated to determine the direction and magnitude of associations among different characters and tested against table ' $\mathrm{t}$ ' values (Fisher and Yates, 1963).

\section{Results and Discussion}

Results on field screening of genotypes for leaf blast reaction revealed that out of eighteen entries, none of the genotypes was found to be highly resistant and 7 genotypes found resistant while remaining 11 genotypes found moderately resistant reaction (The information on SES scores of individual entries is given in Table 1).
The mean performance of individual rice genotypes revealed that the genotype IET$25152(61.33 \mathrm{~cm})$ was found shortest while IET-25149 $(94.33 \mathrm{~cm})$ found to be the tallest. The maximum number of panicles/plant was observed in IET-25156 (17.33) while IET25144 (8.17) showed minimum number of panicles/plant. The same genotypes recorded maximum (755.04) and minimum (355.74) number of panicles $/ \mathrm{m}^{2}$ area respectively. The rice genotypes in present study differed significantly for grain yield. IET-25148 gave maximum grain yield $(4562.27 \mathrm{~kg} / \mathrm{ha})$ followed by IET-25144 (4250.89 $\mathrm{kg} / \mathrm{ha})$ whereas IET-25154 recorded lowest grain yield $(855.87 \mathrm{~kg} / \mathrm{ha})$. Out of 7 resistant entries, one entry namely IET-25148 out yielded $14.20 \%$ over the local check Tunga $(3101.42 \mathrm{Kg} / \mathrm{ha})$. The moderately resistant entries IET-25144 and IET-25151 gave $11.09 \%$ and $10.44 \%$ more yield than local check respectively. Similar findings on mean performance of rice genotypes for various traits were also reported by Hammound (2005), Sedeek et al., (2009) and Anis et al., (2016).

The analysis of variance (Table 2) revealed that sum of squares due to genotypes were highly significant for all the characters under study which indicated enough variability existed among the genotypes. The observed differences among the genotypes may be attributed to their different geographical origin. Similar reports on phenotypic variation among rice genotypes were observed by Elayaraja et al., (2005) and Pandey et al., (2009).

The estimation of genetic parameters indicated that phenotypic variance was higher than genotypic variance for all the traits which revealed considerable effect of environment on the expression of these traits. Consequently phenotypic coefficient of variation $(\mathrm{PCV})$ was higher than genotypic 
coefficient of variation (GCV) for all the characters. The estimates of PCV were high for grain yield $(39.27 \%)$ followed by number of panicles/plant and number of panicles $/ \mathrm{m}^{2}$ area $(22.08 \%)$ and while moderate PCV value was observed for days to $50 \%$ flowering $(14.48 \%)$ and plant height $(12.16 \%)$.

Similarly, GCV were high for grain yield $(37.24 \%)$ followed by number of panicles/plant and number of panicles $/ \mathrm{m}^{2}$ area $(21.20 \%)$ and while low GCV values were observed for days to $50 \%$ flowering (14.10 $\%)$ and plant height (12.09\%) percent variability is represented graphically in Figure 1. Similar findings were reported by Jayasudha and Sharma (2010) studies on genetic variability, character association and path-coefficient analysis were conducted on forty seven (47) rice genotypes including thirty three hybrids and fourteen parents for grain yield and some physiological traits.

The large difference between PCV and GCV values observed for grain yield/ha followed by number of panicles per plant and number of panicles $/ \mathrm{m}^{2}$ area indicated large effect of environment on the expression of these traits.

On the contrary, 100 seed weight and straw yield were least affected by environment as indicated by less difference between PCV and GCV values. Ramanjaneyulu et al., (2014) also reported less difference between PCV and GCV for plant height.

The estimates of PCV and GCV clearly indicate the presence of degree of genetic variation; however, it is the estimates of heritability and genetic advance which determine the amount of heritable portion of variation. According to Lush (1949), heritability (broad sense) is the ratio of genotypic variance to phenotypic variance, expressed in percentage. Heritability is classified as high (above 60\%), medium (30\%
- 60\%) and low (below 30\%). The estimates of heritability are more advantageous when expressed in terms of genetic advance.

High estimates of heritability were exhibited for all the character under study (Table 3).

The estimates of heritability (broad sense) ranged from 89.95 percent to 98.91 percent. Plant height $(98.91 \%)$ showed highest heritability followed by days to $50 \%$ flowering (94.82\%) and grain yield/ha $(89.95 \%)$, whereas number of panicles per plant as well as number of panicles $/ \mathrm{m}^{2}$ showed equal heritability (92.17\%).

Similar findings of high heritability for grain yield were reported by Panwar (2005), Kumar et al., (2007) and Chaurasia et al., (2012).

High heritability values of a trait indicate less effect of environment on their expression. The plant breeder, therefore adopt simple selection method on the basis of the phenotype of the characters which ultimately improves the genetic background of these traits. The estimates of genetic advance as per cent of mean provide more reliable information regarding the effectiveness of selection in improving the traits.

Genetic advance denotes the improvement in the mean performance of the selected individuals over the base population. Perusal of table 3 revealed high estimates of genetic advance for the traits under study.

The genetic advance as per cent of mean was found to be highest for grain yield/ha $(72.76 \%)$ followed by number of panicles per plant as well as number of panicles $/ \mathrm{m}^{2}$ which showed equal genetic advance as percent of mean $(41.92 \%)$, days to $50 \%$ flowering (28.28\%) and plant height $(24.77 \%)$ percent heritability and genetic advance is graphically represented in Figure 1. 
Table.1 Mean performance of 18 early maturing rice genotypes under hilly condition

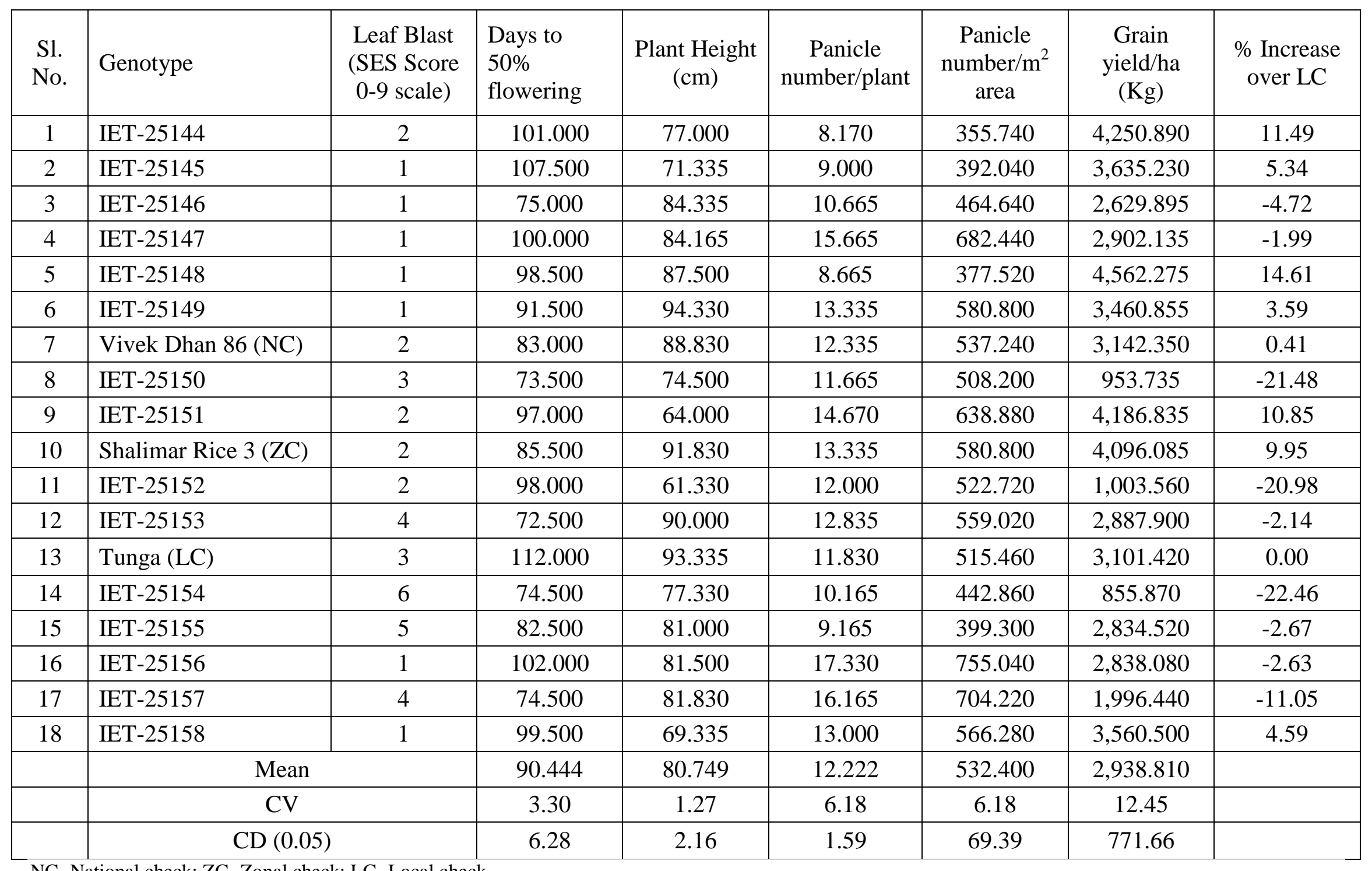

NC- National check; ZC- Zonal check; LC- Local check. 
Table.2 ANOVA for different yield related traits in rice genotypes

\begin{tabular}{|l|c|c|c|c|c|c|}
\hline \multirow{2}{*}{$\begin{array}{l}\text { Source of } \\
\text { variation }\end{array}$} & d.f. & $\begin{array}{c}\text { Days to } \\
50 \% \\
\text { flowering }\end{array}$ & $\begin{array}{c}\text { Plant } \\
\text { Height } \\
(\mathrm{cm})\end{array}$ & $\begin{array}{c}\text { Panicle } \\
\text { number/plant }\end{array}$ & $\begin{array}{c}\text { Panicle } \\
\text { number/m } \\
\text { area }\end{array}$ & $\begin{array}{c}\text { Grain yield/ha } \\
(\mathrm{Kg})\end{array}$ \\
\hline Replication & 1 & 4.00 & 14.71 & 5.98 & 11337.99 & 197356.58 \\
\hline Genotypes & 17 & $333.99^{* *}$ & $191.74^{* *}$ & $13.99^{* *}$ & $26552.23^{* *}$ & $2529264.59^{* *}$ \\
\hline Error & 17 & 8.88 & 1.05 & 0.57 & 1081.71 & 133772.21 \\
\hline
\end{tabular}

** indicates significance at $1 \%$ level of significance

Table.3 Estimates of mean and other genetic parameters for different yield and yield attributing traits in rice genotypes

\begin{tabular}{|c|c|c|c|c|c|c|c|}
\hline \multirow{2}{*}{$\begin{array}{l}\text { Sl. } \\
\text { No. }\end{array}$} & \multirow{2}{*}{ Character } & \multicolumn{2}{|c|}{ Variances } & \multicolumn{2}{|c|}{$\begin{array}{c}\text { Coefficient of } \\
\text { variation } \%\end{array}$} & \multirow{2}{*}{$\begin{array}{c}\mathrm{h}^{2} \text { bs } \\
(\%)\end{array}$} & \multirow{2}{*}{$\begin{array}{c}\text { GAM } \\
(\%)\end{array}$} \\
\hline & & $\mathrm{Vg}$ & $\mathrm{Vp}$ & GCV & $\mathrm{PCV}$ & & \\
\hline 1 & $\begin{array}{l}\text { Days to 50\% } \\
\text { flowering }\end{array}$ & 162.56 & 171.44 & 14.10 & 14.48 & 94.82 & 28.28 \\
\hline 2 & Plant Height $(\mathrm{cm})$ & 95.35 & 96.40 & 12.09 & 12.16 & 98.91 & 24.77 \\
\hline 3 & Panicle number/plant & 6.71 & 7.28 & 21.20 & 22.08 & 92.17 & 41.92 \\
\hline 4 & $\begin{array}{l}\text { Panicle number } / \mathrm{m}^{2} \\
\text { area }\end{array}$ & 12735.26 & 13816.97 & 21.20 & 22.08 & 92.17 & 41.92 \\
\hline 5 & Grain yield/ha $(\mathrm{Kg})$ & 1197745.42 & 1331518.19 & 37.24 & 39.27 & 89.95 & 72.76 \\
\hline
\end{tabular}

Vg: Genotypic variance, Vp: Phenotypc variance, GCV: Genotypic coefficient of variation, PCV: Phenotypic coefficient of variation, $h^{2}$ bs: Broad sense heritability, GAM: Genetic advance as percent of mean.

Table.4 Phenotypic and genotypic correlation matrix for yield and yield related traits

\begin{tabular}{|l|l|l|l|l|l|}
\hline & $\begin{array}{c}\text { Days to 50\% } \\
\text { flowering }\end{array}$ & $\begin{array}{c}\text { Plant Height } \\
(\mathrm{cm})\end{array}$ & $\begin{array}{c}\text { Panicle } \\
\text { number/plant }\end{array}$ & $\begin{array}{c}\text { Panicle } \\
\text { number/m }{ }^{2} \text { area }\end{array}$ & $\begin{array}{l}\text { Grain yield/ha } \\
(\mathrm{Kg})\end{array}$ \\
\hline $\begin{array}{l}\text { Days to 50\% } \\
\text { flowering }\end{array}$ & 1 & $-0.176^{\mathrm{NS}}$ & $-0.010^{\mathrm{NS}}$ & $-0.030^{\mathrm{NS}}$ & $0.470^{* *}$ \\
\hline $\begin{array}{l}\text { Plant Height } \\
(\mathrm{cm})\end{array}$ & $-0.176^{\mathrm{NS}}$ & 1 & $0.065^{\mathrm{NS}}$ & $0.062^{\mathrm{NS}}$ & $0.261^{\mathrm{NS}}$ \\
\hline $\begin{array}{l}\text { Panicle } \\
\text { number/plant }\end{array}$ & $-0.012^{\mathrm{NS}}$ & $0.067^{\mathrm{NS}}$ & 1 & $0.922^{* *}$ & $-0.113^{\mathrm{NS}}$ \\
\hline $\begin{array}{l}\text { Panicle } \\
\text { number/m } \\
\text { area }\end{array}$ & $-0.032^{\mathrm{NS}}$ & $0.070^{\mathrm{NS}}$ & $0.980^{* *}$ & 1 & $-0.104^{\mathrm{NS}}$ \\
\hline $\begin{array}{l}\text { Grain yield/ha } \\
(\mathrm{Kg})\end{array}$ & $0.510^{* *}$ & $0.270^{\mathrm{NS}}$ & $-0.113^{\mathrm{NS}}$ & $-0.120^{\mathrm{NS}}$ & 1 \\
\hline
\end{tabular}

** Significant at $1 \%$ level of significance. Values above the diagonal represent phenotypic correlation; Values below the diagonal represent genotypic correlation 


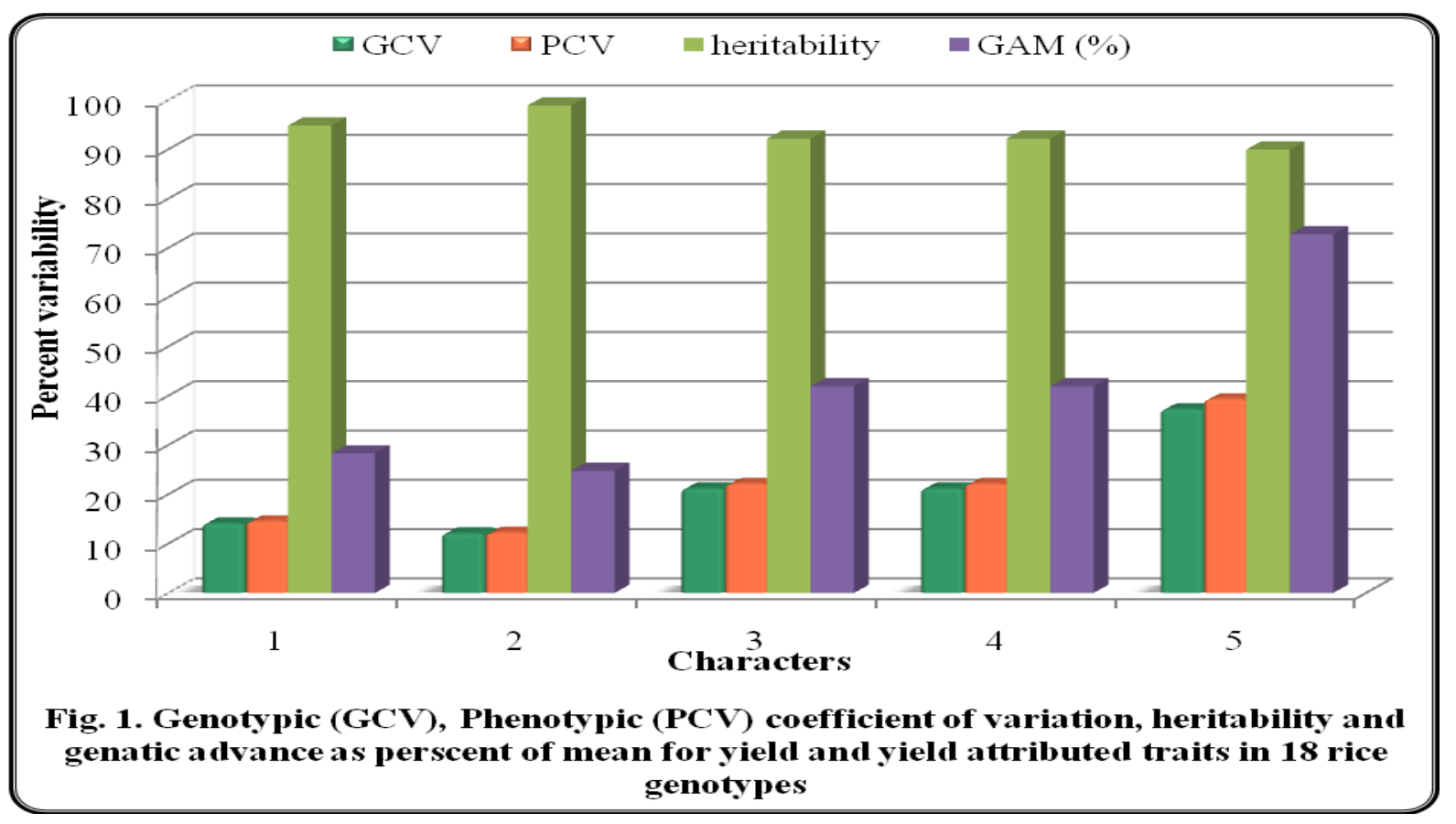

Since the broad sense heritability includes both additive and non-additive components of genetic variance, heritability alone will not be of much practical value hence the concurrent use of genetic advance along with heritability would be more useful in predicting the resultant effect of selection on phenotypic expression (Johnson et al., 1955). In the present study, grain yield/ha, number of panicles/plant and number of panicles $/ \mathrm{m}^{2}$ area showed high genotypic variance, high heritability and high genetic advance whereas high heritability and high genetic advance along with moderate genotypic variance was observed for days $50 \%$ flowering and plant height. These findings were in accordance with the results of Dhanwani et al., (2013) studied the higher magnitude of PCV and GCV was recorded for number of grains per panicle $(23.85 \% ; 23.10 \%)$ and grain yield per plant $(23.17 \% ; 22.04 \%)$. The additive gene action is involved in the expression of those characters which show high genotypic variance coupled with high heritability and genetic advance (Panse, 1957) thus can be improved through simple or progeny selection methods while the characters with high heritability coupled with moderate or low genetic advance can be improved by inter-mating superior individuals from segregating population of a cross (Samadhia, 2005).

To break the yield barriers in rice breeding strategies, attempts are being made to estimate correlations between dependent and independent characters. The grain yield is a complex character dependent on many component characters and it responds poorly to the direct selection. For the improvement of grain yield, the knowledge on the association between grain yield and its component characters will be helpful. This correlation coefficient analysis is helpful in deciding the possibility of improvement of a character through selection for other character.

The phenotype of a plant is result of interaction of large number of factors. Hence final yield is the sum of total effect of several component factors. Therefore, it is important to know the extent and nature of inter-relationship raveling between grain yield and its component characters and also among themselves. This would be obtaining from simple correlation coefficient which helps a breeder in determining the direction and number of characters to be considered in improving yield and grain quality. 
The present study was, therefore, undertaken to understand the association among grain yield and its component traits in the genotypes under study.

Phenotypic correlation studies showed that the days to $50 \%$ flowering exhibited significant positive correlation with grain yield/ha (0.47), while number panicles/plant exhibited positive significant correlation with number panicles $/ \mathrm{m}^{2}$ area (0.92). Whereas remaining traits exhibited non-significant correlations with yield (phenotypic correlation values are given in table 4 in upper diagonal). Genotypic correlation studies showed similar association pattern. Days to $50 \%$ flowering had positively significant correlation with grain yield/ha $(0.51)$, while number panicles/plant exhibited positive significant correlation with number panicles $/ \mathrm{m}^{2}$ area (0.98). Whereas remaining traits exhibited non-significant correlations with yield (genotypic correlation values are given in table 4 in lower diagonal).

This indicates the relative utility of all these traits for selection with respect to grain yield. Rajeshwari and Nadarajan (2004) observed positive significant correlation with yield for days to $50 \%$ flowering. The results suggest that negative correlations with filled grains leads to lower yield which means early maturing varieties produced lower yields. These results are in accordance with the results of Hasan et al., (2013), who found days to $50 \%$ flowering was negatively correlated with yield.

The present investigation was carried out in order to study the nature and amount of variability, heritability and genetic advance and association between traits under study. From the investigation it is concluded that the blast resistant entry IET-25148 and moderately resistant entries IET-25144 and IET-25151 found superior than the local check Tunga and these entries could be advanced for further improvement or they could be used as parents in further breeding. Based on mean performance of individual rice genotypes the genotype IET25152 followed by IET-25151 can be selected for the dwarfness trait, while the genotype IET25149 can be selected for tallness trait.

The genotypes IET-25156 and IET-25156 recorded higher number of panicles/plant as well as number of panicles $/ \mathrm{m}^{2}$. Analysis of variance revealed highly significant sum of squares due to genotypes for all the characters indicated the existence of ample variability among the genotypes. The estimates of PCV were higher than the GCV which indicated high influence of environment on the expression of the traits. The traits like number of panicles/plant, number of panicles/ $\mathrm{m}^{2}$ and yield which exhibited high genotypic variance, high heritability coupled with high genetic advance as percent of mean can be considered as relative measures of selection for the higher yield. Based on correlation studies traits like days to $50 \%$ flowering, number of panicles/plant and number of panicles $/ \mathrm{m}^{2}$ can be considered for their simultaneous improvement towards yield.

\section{References}

Anis, G., Sabagh, A. E. L., Ghareb, A. and ELRewainy, I., 2016, Evaluation of promising lines in rice (Oryza sativa L.) to agronomic and genetic performance under Egyptian conditions. Intern. J. Agron. and Agri. Res. 8 (3): 52-57.

Anonymous, 2014, KSDA data, http//raitamitra.kar.nic.in/

Anonymous, 2015, KSDA data, http//raitamitra.kar.nic.in/

Burton, G. W., 1952, Quantitative inheritance in grasses. Proc. VI. Institute Grassland Congr, 1:155-157.

Chaurasia, A. K., Rai, P. K. and Kumar, A., 2012, Estimation of genetic variability, heritability and genetic advance in aromatic fine grain rice. Romanian J. of Bio. Pl. Bio. (Bucharest) 57: 71-76.

Dhanwani, R. K., Sarawgi, A. K., Solanki, A. and Tiwari, J. K., 2013, Genetic variability analysis for various yield attributing and quality traits in rice $(O$. Sativa L.). The Bioscan. 8(4): 1403-1407.

Elayaraja, K., Prakash, M., Saravana, K., Kuma, B. S. and Ganesan, J., 2005, Studies on 
variability, heritability and genetic advance for quantitative characters in rice (Oryza sativa L.) Crop Res. 29: 134-137.

Fisher, R. A. and Yates, F., 1963, Statistical Tables for Biol. Agric and Medic Res., Oliver and Boyd, London. pp. 46-63.

Hammoud S. A., 2005, Genetic behavior of some agronomic characters in two rice crosses. Egypt. J. Agric. Res. 83(5):305322.

Hasan, M. J., Kulsum, M. U., Akter, A., Masuduzzaman, A. S. M. and Ramesha, M. S., 2013, Genetic variability and character association for agronomic traits in hybrid rice (Oryza sativa L.). Bangladesh Journal of Plant Breeding and Genetics, 24(1), 45-51.

Jayasudha, S. and Sharma, D., 2010, Genetic parameters of variability, correlation and path-coefficient for grain yield and physiological traits in rice (Oryza sativa L.) under shallow low land situation. Electronic J. of Pl. Breeding 1(5): 33-38.

Johnson, H. W., Robinson, H. F. and Comstock, R. E., 1955, Estimates of genetic and environmental variability in Soybean. Agron J. 47:314-318.

Kumar, S. T., Narasimman, R., Eswaran, R., Kumar, C. P. S. and Anandan, A., 2007, Studies on genetic variability, heritability and genetic advance in segregating generations of rice (Oryza sativa L.). Intern. J. of Pl. Sci. 2: 48-51.

Lush, J. L., 1949, Inter-se, correlation and regression of characters. Proceeding of American Society of Animal Production. 33: 293-301.

Pandey, P., John, P., Anurag, Tiwari, D. K., Yadav, S. K. and Kumar, B., 2009, Genetic variability, diversity and association of quantitative traits with grain yield in rice (Oryza sativa L.). J. of
Bio-Sci., 17(1): 77-82.

Panse, V. G. and Shukhatme, P. V., 1967, Statistical Methods for agricultural workers. $2^{\text {nd }}$ edition, ICAR, New Delhi: 152-157.

Panse, V. G., 1957, Genetics of quantitative characters in relation to plant breeding. Ind. J. of Genetics and Plant Breeding 17: 318-328.

Panwar, L. L., 2005, Genetic variability, heritability and genetic advance for panicle characters in transplanted rice (Oryza sativa L.). Agric. Res. Stat. 3: 505508.

Rajeshwari, S. and Nadarajan, N., 2004, Correlation between yield and yield components in rice (Oryza sativa L.). Agric. Sci. Dig., 24:280-282.

Ramanjaneyulu, A. V., Gouri Shankar, V., Neelima, T. L. and Shashibhusahn, D., 2014, Genetic analysis of rice (Oryza sativa 1.) genotypes under aerobic conditions on alfisols. SABRAO J. Breeding and Genetics 46 (1): 99-111.

Samadhia, D. K., 2005, Genetic variability studies in Lasora (Cordiamyxa Roxb.). Indian J. of Pl. Genetic Res., 18(3): 236240.

Sedeek, S. M., Hammoud, S. A., Ammar, M.H. and Metwally, T. F., 2009, Genetic variability, heritability, genetic advance and cluster analysis for some physiological traits and grain yield and its components in rice (Oryza sativa L.). J. of Agri. Res. 35(3):858-878.

Shrivastava, A., Mishra, D. K. and Koutu, G. K., 2015, estimation of genetic parameters of variability for yield and its attributing traits in parental lines of hybrid rice. Plant Archives, 15(1): 571574.

\section{How to cite this article:}

Hosagoudar, G.N., Basavaraj S. Kovi and Sheela, H.K. 2017. Genetic Variability, Correlation and Leaf Blast Resistance Studies in Early Maturing Rice Genotypes under Hilly Conditions. Int.J.Curr.Microbiol.App.Sci. 6(12): 3451-3459. doi: https://doi.org/10.20546/ijcmas.2017.612.401 